\title{
Comparison of Hydroxyethyl starch 130/0.4 (6\%) with commonly used agents in an experimental Pleurodesis model
}

\author{
Hasan Oğuz Kapicibasi ${ }^{1 *} \mathbb{D}$, Hasan Ali Kiraz² (D) and Nazli Demir Gök ${ }^{3} \mathbb{B}$
}

\begin{abstract}
Background: Hydroxyethyl Starch (HES) 130/0.4 (6\%) is a commonly used intravascular volume expander with antiinflammatory and antioxidant properties. In this study, we aimed to compare the histopathologic activity of HES 130/0.4 (6\%) with various widely-used agents in pleurodesis.

Methods: Forty male Wistar-Albino rats were divided into five groups: controls, povidone-iodine recipients (PI group), sterile talcum recipients (Talcum group), autologous blood recipients (AB group) and HES 130/0.4 (6\%) recipients (HES group). Thirty days after application of agents, pleural and lung tissues were resected. Evaluation was performed via macroscopic scoring (adhesion) and specimens were stained with H\&E for microscopic examination (inflammation and fibrosis).

Results: HES recipients had significantly higher adhesion compared to controls (lower grade 0, higher grade 1 frequency vs. controls), they were found to have significantly lower frequency of grade 2 adhesion (vs. Pl, Talc and $A B$ ) and grade 3 adhesion (vs. $A B$ ), indicating that the adhesion-generating properties of HES were only superior to the control group. HES recipients had significantly higher inflammatory grades compared to controls (lower grade 0, higher grade 1 frequency), while they had lower grades compared to the PI, Talc and $A B$ groups. Although the PI, Talc and $A B$ groups were statistically similar in most comparisons, we observed a trend towards higher success with the use of Talc and especially AB.

Conclusion: Our results do not support a role for HES in pleurodesis. We believe that the autologous blood method remains as an effective and successful procedure without side effects.
\end{abstract}

Keywords: Parietal-visceral pleura, Pleurodesis, Hydroxyethyl starch

\section{Background}

Pleurodesis is a procedure in which the anatomical space between the parietal and visceral pleura is removed by the adhesion of these two layers. While adhesion can be achieved mechanically by abrasion via thoracoscopy or thoracotomy, chemical pleurodesis is very common with the application of an agent via thoracoscopy and chest

\footnotetext{
* Correspondence: droguzkapicibasi@gmail.com

'Department of Thoracic Surgery, Canakkale Onsekiz Mart University, Faculty of Medicine, Canakkale, Turkey

Full list of author information is available at the end of the article
}

tube insertion. The most frequently used agent in the latter approach to pleurodesis is talcum powder, also known as talc [1]. However, when the research concerning pleurodesis methods is evaluated, it is evident that there is no "ideal" agent for pleurodesis [2], and success rates with different agents vary greatly, from 54 to $93 \%$ [3].

An ideal agent for chemical pleurodesis should be easy to apply, effective, accessible, inexpensive and must have minimal side effects. Due to these prerequisites, the literature has focused on the use of autologous blood $(\mathrm{AB})$ and povidone-iodine (PI) as alternatives for chemical

(c) The Author(s). 2020 Open Access This article is licensed under a Creative Commons Attribution 4.0 International License, which permits use, sharing, adaptation, distribution and reproduction in any medium or format, as long as you give appropriate credit to the original author(s) and the source, provide a link to the Creative Commons licence, and indicate if changes were made. The images or other third party material in this article are included in the article's Creative Commons licence, unless indicated otherwise in a credit line to the material. If material is not included in the article's Creative Commons licence and your intended use is not permitted by statutory regulation or exceeds the permitted use, you will need to obtain permission directly from the copyright holder. To view a copy of this licence, visit http://creativecommons.org/licenses/by/4.0/ The Creative Commons Public Domain Dedication waiver (http://creativecommons.org/publicdomain/zero/1.0/) applies to the data made available in this article, unless otherwise stated in a credit line to the data. 
pleurodesis [4-6]. Although talc pleurodesis is still very common, reports have shown possibility of serious adverse effects, including acute respiratory distress [7-9]. Hydroxyethyl starch (HES) 130/0.4 (6\%) (Voluven ${ }^{\circ}$, Fresenius Kabi, Germany) is a corn-based intravascular volume expander that is readily used during the perioperative period and in intensive care units. Studies have shown that this colloid solution has antioxidant and anti-inflammatory properties, which may be associated with its positive contribution to ventilation and oxygenation [10]. Moreover, HES has been reported to be associated with a reduction in the need for blood transfusion in major surgical procedures [11].

Epidural blood patch application is considered as the gold standard approach in patients unresponsive to symptomatic treatment; however, in cases where the use of autologous blood is contraindicated, the introduction of HES 130/0.4 (6\%) into the epidural space has been reported as a suitable alternative [12], indicating that HES may be a safe and effective option in other scenarios. In the lung, $\mathrm{AB}$ patches are utilized in clinical and experimental studies with considerable success for various conditions. Therefore, evaluation of the efficacy of HES in chemical pleurodesis may be important to identify alternative methods.

This study aimed to compare and evaluate the effectiveness of the corn-based, easy-accessible volume expander HES 130/0.4 (6\%) with other widely-used agents for pleurodesis, in terms of efficacy and histopathological outcomes.

\section{Methods}

Forty male Wistar-Albino rats suitable for the study conditions, weighing 350-450 g, were included in the study. Ethical approval was obtained from the Canakkale Onsekiz Mart University Ethical Board of Animal Studies (2018/1800097318). All rats were subjected to a general clinical examination of behavior and respiratory and cardiovascular characteristics at the beginning of the study and on a weekly basis after interventions by a member of the research staff (excessive pain symptoms, changes in behavior, activity). Additionally, the animals were regularly followed by veterinarians who were staffed at the animal studies laboratory. Rats were kept in appropriate-sized cages and were fed ad libitum with standard rodent chow during the course of the study. Ambient temperature was set at $21 \pm 2 \mathrm{C}$ degrees and a normal daily light cycle was simulated by $12 \mathrm{~h}$ of light and dark. All rats were cared for in accordance with the "Regulation on the Welfare and Protection of Animals Used for Experimental and Other Scientific Purposes (13.12.2011-28141)" prepared by the Ministry of Food, Agriculture and Livestock.
After the adaptation period, forty rats were randomly allocated into five groups of eight rats each:

- Controls (sham control group, $n=8$ ): This was the control group which underwent the same procedures but received intrapleural $2 \mathrm{~mL} / \mathrm{kg}$ physiological saline (SF).

- Povidone-iodine group (PI group, $n=8$ ): Rats in this group were administered intrapleural $2 \mathrm{~mL} / \mathrm{kg}$ povidone-iodine (\%10) [13-15].

- Sterile talcum group (Talc group, $n=8$ ): Rats in this group received intrapleural $2 \mathrm{~mL} / \mathrm{kg}$ sterile talcum.

- Autologous blood group (AB group, $n=8$ ): Rats in this group were administered intrapleural autologous blood obtained from the subclavian vein (Fig. 1) at a dose of $(2 \mathrm{~mL} / \mathrm{kg})$ as described by Özpolat and colleagues [16].

- Hydroxyethyl starch (130/0.4, 6\%) (HES group, $n=$ 8): Rats in this group were administered intrapleural corn-based HES 130/0.4 (6\%) $2 \mathrm{~mL} / \mathrm{kg}$.

\section{Surgical procedures}

Intrapleural administration was performed in all groups. After necessary skin preparation and following general anesthesia (xylazine $-5 \mathrm{mg} / \mathrm{kg}$ and ketamine $-50 \mathrm{mg} / \mathrm{kg}$, intramuscular), a $3-5 \mathrm{~mm}$ skin incision was made under the 5th intercostal space of the right hemithorax under sterile conditions. Using a 22-Gauge polytetrafluoroethylene (PTFE) catheter, agents were applied to the pleural space with the aid of a three-way tap. (Fig. 1).

The presence of air in the pleural space was controlled. If air was present in the pleural cavity, it was removed with the help of the a triple tap. The pleural catheterization was then terminated and the skin was sutured. The rats were then slowly rotated to enable the spread of agents to the entire pleura. All interventional procedures were carried out from $8 \mathrm{AM}$ to $11 \mathrm{AM}$.

Two rats from the PI group died immediately after the procedure. One rat from the sterile talc and one from autologous blood groups were lost on the 7th and 13th days due to surgical complications (Fig. 2).

Thirty days after the procedures, the rats were sacrificed via administering high dose anesthetic (xylazine $10 \mathrm{mg} / \mathrm{kg}$ and ketamine $-80 \mathrm{mg} / \mathrm{kg}$, intramuscular), right hemithorax ribs were cut from sternal junctions, and the pleural spaces were exposed. Pleural and lung tissue sampling was performed after macroscopic scoring in all groups. The macroscopic scoring of pleurodesis was determined by a surgeon and a blinded pathologist according to the method described by Hurewitz et al. [17]: Grade $0=$ Normal pleura; Grade $1=$ Adhesions at several sites, Grade $2=$ Widely dispersed adhesion, and Grade $3=$ Complete adherence to the pleural space. The specimens were then fixed with formalin. 


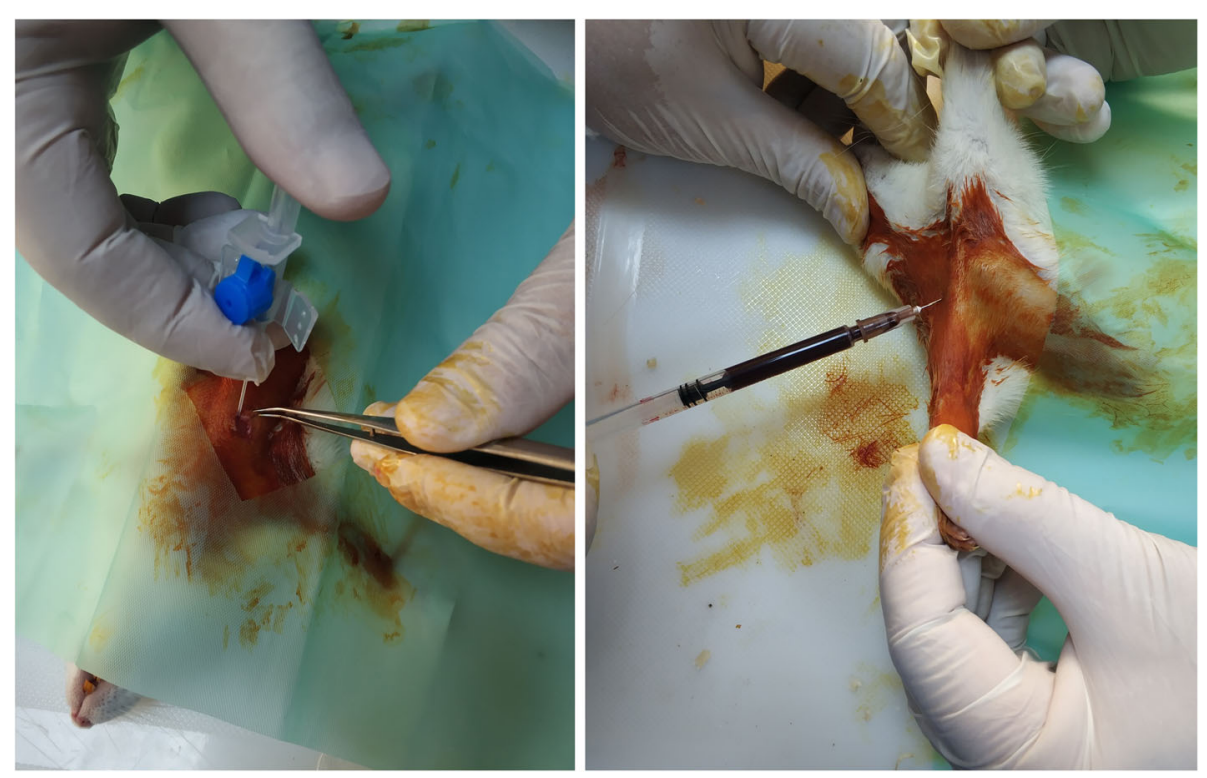

Fig. 1 The surgical procedure. Cannulation (a) and blood tapping (b) from the subclavian vein for autologous pleurodesis

\section{Histopathological analysis}

The obtained lung tissue samples were fixed in 10\% formalin solution. After $24 \mathrm{~h}$ of fixation, the tissues were transferred to cassettes according to the groups. The tissues were then embedded in paraffin and sections of 4- $\mu \mathrm{m}$ thickness were taken for hematoxylin \& eosin (H\&E) staining. The resultant samples were examined under a light microscope. The examining pathologists were blinded to the groups. The peribronchial, perivascular, and parenchymal inflammatory cell infiltration and fibrosis findings in the tissues were scored and classified categorically according to the degree of inflammation (Grade 0: none, Grade 1: $>0-5 \%$, Grade 2: $>5-30 \%=2$, and Grade 3: $>30 \%$ ).

\section{Statistical analysis}

The applied method and the minimum number of animals required for scientific results were taken into consideration with regard to the reports of previous studies which had utilized groups comprising of 6 to 10 animals $[16,18-20]$. With this data in mind, we used the values reported by Ozpolat et al. (microscopic scoring results with $2 \mathrm{ml} / \mathrm{kg} \mathrm{AB}$ application, mean $\pm \mathrm{SD}=1.86 \pm 0.69$ ) and determined a $50 \%$ change in mean value to be significant. This study was chosen because it had utilized $\mathrm{AB}$ which is a safe and frequently used approach, also it had relatively low standard deviation compared to other studies. The number of animals required for the comparison of groups was calculated as 8 -with $80 \%$ power

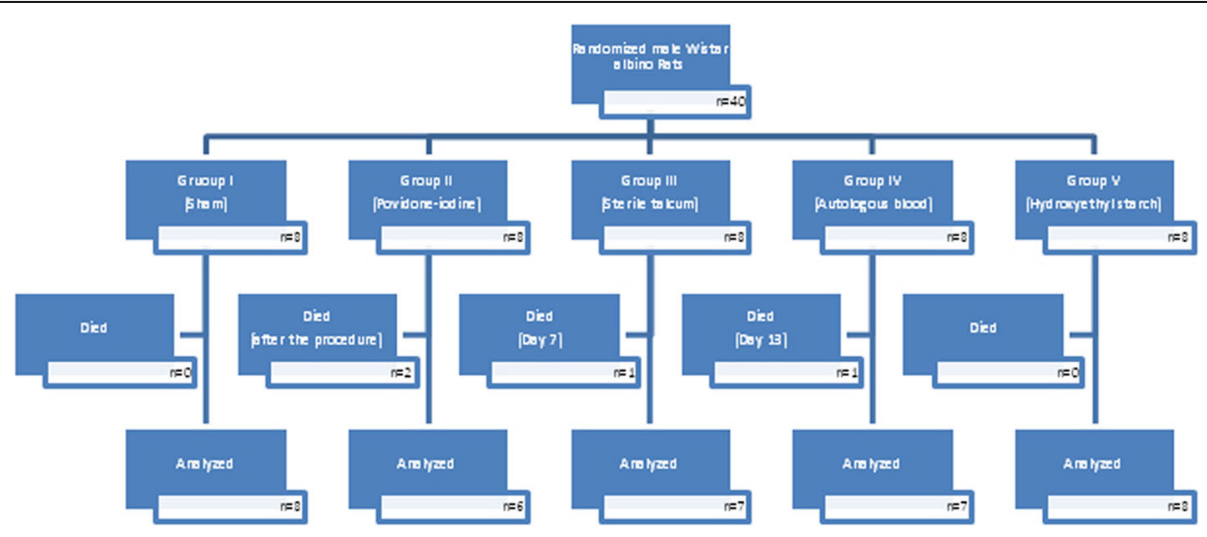

Fig. 2 Study flow chart 
and an alpha error of 5\%. The Statistical Package for the Social Sciences (SPSS) version 25.0 software (SPSS Inc., Chicago, IL, USA) was used for data analysis. The groups were compared with the Pearson Chi-square test; subset comparisons were performed via the use of Zscore comparisons for column proportions. No correction was made in terms of multiple hypothesis testing. $P$-values of $\leq 0.05$ were accepted as significant.

\section{Results}

After the conduct of interventions, two rats in the PI group had died; thus, analysis was performed with 6 rats in this group. Additionally, one rat each from the Talc and $A B$ groups died (on the 7th and 13th days after intervention, respectively), reducing the total rat count in these groups to 7 rats each. All remaining animals were included in the analyses, since none were excluded or euthanized prematurely during follow-up evaluations.

\section{Macroscopic findings}

Overall comparison of adhesion grades in the 5 groups showed a statistically significant difference between groups (Pearson Chi-square, $p<0.001$ ). In the control group, all rats were classified as "normal pleura" (grade 0 ). Grade 2 and 3 adhesions were significantly more common in the $\mathrm{AB}$ group compared to the HES group and controls. Although there was no significant difference between the frequency of grade 2 and 3 adhesions in the comparison of the PI, Talc and $\mathrm{AB}$ groups, we observed a trend towards higher frequency of grade 3 adhesion in the $\mathrm{AB}$ group $(42.9 \%)$ compared to the Talc $(14.3 \%)$ and PI $(0 \%)$ groups (Table 1). Although HES recipients had significantly higher adhesion compared to controls (lower grade 0 , higher grade 1 frequency vs. controls), they were found to have significantly lower frequency of grade 2 adhesion (vs. PI, Talc and $\mathrm{AB}$ ) and grade 3 adhesion (vs. $\mathrm{AB}$ ), indicating that the adhesion-generating properties of HES were only superior to the control group. Of note, 3 subjects from the $A B$ group (42.9\%) and 1 subject from the Talc group (14.3\%) had complete adherence of the pleura. When the contralateral pleural surfaces were evaluated, we found no adhesions in the parietal, visceral, and mediastinal surfaces (Fig. 3).

\section{Histopathological findings}

Overall comparison showed a statistically significant difference in terms of the distribution of inflammation grades in the study groups (Pearson Chi-square, $p<$ 0.001). The distributions within groups were similar to those observed with adhesion (macroscopic characteristics). Seven of the subjects in the control group had no inflammation and one subject had grade 1 inflammation. In the HES group, 3 (37.5\%) had grade 0 and 5 (62.5\%) had grade 1 inflammation. Comparisons revealed that HES recipients had significantly higher inflammatory grades compared to controls (lower grade 0, higher grade 1 frequency), while they had lower grades compared to the PI, Talc and AB groups. There were no statistically relevant differences between the PI, Talc and $\mathrm{AB}$ groups in terms of inflammatory grade distribution; however, we again observed a trend towards higher levels of inflammation (grade $2+3$ ) in the $\mathrm{AB}$ group $(n=5,71.4 \%)$ compared to the PI group $(n=3,50 \%)$ and the Talc group $(n=4,57.1 \%)$. Of note, in the whole study group $(n=36)$ only the AB group had grade 3 inflammation $(n=2)$ (Table 2).

When fibrosis was evaluated, overall comparison demonstrated the presence of a statistically significant variation in the distributions of groups (Pearson Chi-square, $p<0.001)$. All subjects in the control $(n=8)$ and HES $(n=8)$ groups were classified as "no fibrosis", indicating no difference between HES and controls in terms of fibrosis. Statistical results only showed that the PI, Talc and $A B$ groups had significantly higher levels of fibrosis in comparison to the control and HES groups. There was no significant difference between the PI, Talc and $A B$ groups with regard to the distribution of fibrosis classifications; however, fibrosis was present in $95 \%$ of the subjects in these 3 groups $(19 / 20)$. Only 1 subject in the Talc group was classified as "no fibrosis" (Table 3).

Evaluation of contralateral surfaces showed that both inflammation and fibrosis were absent from the parietal,

Table 1 Comparison of pleural adhesion levels between the experimental groups

\begin{tabular}{|c|c|c|c|c|c|c|c|c|c|c|}
\hline & \multicolumn{2}{|c|}{ Control $(n=8)$} & \multicolumn{2}{|c|}{$\mathrm{PI}(n=6)$} & \multicolumn{2}{|c|}{ Talc $(n=7)$} & \multicolumn{2}{|c|}{$\mathrm{AB}(n=7)$} & \multicolumn{2}{|c|}{ HES $(n=8)$} \\
\hline & $\bar{n}$ & $\%$ & $\bar{n}$ & $\%$ & $\bar{n}$ & $\%$ & $\bar{n}$ & $\%$ & $\bar{n}$ & $\%$ \\
\hline Normal pleura & $8 \mathrm{a}$ & 100 & $\mathrm{O}_{\mathrm{b}}$ & 0 & $O_{b}$ & 0 & $0_{b}$ & 0 & $4 c$ & 50 \\
\hline Adhesions at several sites & $\mathrm{O}_{\mathrm{a}}$ & 0 & $2 a, b$ & 33.3 & $\mathrm{O}_{\mathrm{a}}$ & 0 & $\mathrm{O}_{a}$ & 0 & $4_{b}$ & 50 \\
\hline Widely dispersed adhesion & $0_{a}$ & 0 & $4_{b}$ & 66.7 & $\sigma_{b}$ & 85.7 & $4 \mathrm{~b}$ & 57.1 & $\mathrm{O}_{\mathrm{a}}$ & 0 \\
\hline Complete adherence & $0_{a}$ & 0 & $0_{a, b}$ & 0.0 & $1_{a, b}$ & 14.3 & $3_{b}$ & 42.9 & $\mathrm{O}_{\mathrm{a}}$ & 0 \\
\hline
\end{tabular}

Pearson Chi-square test with subset comparison for column proportions. Chi-Square $=48.816, p<0.001$. Percentages represent column proportion. The same letters indicate the lack of significant difference from other group subsets (No correction for multiple hypothesis testing) 


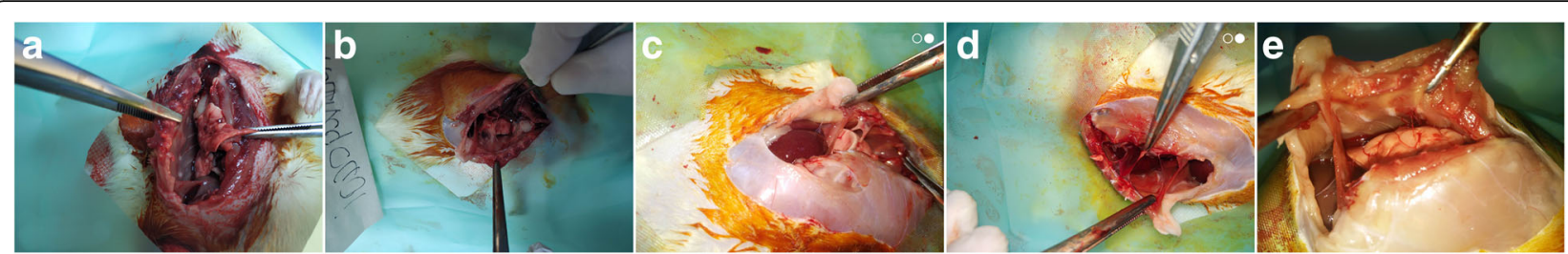

Fig. 3 Macroscopic appearances in the different groups. a Macroscopic appearance in the SF group. b Macroscopic appearance in the povidoneiodine group. c Macroscopic appearance in the autologous pleurodesis group. $\mathbf{d}$ Macroscopic appearance in the sterile talcum group. e Macroscopic appearance in the HES 130/0.4 (6\%) group

visceral and mediastinal pleural surfaces, as well as the lung and diaphragm (Fig. 4).

\section{Discussion}

Historically, various agents (PI, minocycline, tetracycline, OK 432, erythromycin, and Talc) have been used to induce pleurodesis [21]. Today, the most popular of these agents are arguably PI, Talc and AB. Our study was aimed at comparing HES with these agents in terms of pleurodesis development. We also performed a detailed review of notable publications using these three agents in comparable animal studies (rats and rabbits) to identify study characteristics, dosage and toxicity of these agents (Table 4).

Talc, tetracycline and doxycycline are agents that are widely used in the treatment of pneumothorax but have potentially devastating side effects, including acute respiratory distress syndrome [22-24]. As a method that did not have similar side effects, $A B$ pleurodesis was first used by Robinson in the treatment of spontaneous pneumothorax [25]. It is relatively safe compared to other forms of chemical pleurodesis, as very few adverse results have been reported [26]. The success rate of $A B$ pleurodesis is reported between 59 and $100 \%$ in different publications reporting clinical results $[6,27-30]$. Various studies have explored the use of $\mathrm{AB}$ in experimental animal studies [31-33]. In an experimental rat study by Ozpolat et al., different volumes of $\mathrm{AB}$ application were evaluated for pleurodesis efficacy, and it was reported that 2 and $3 \mathrm{ml} /$ $\mathrm{kg}$ volumes were successful, while $1 \mathrm{ml} / \mathrm{kg}$ was ineffective [16]. It is also important to note that some animal studies have investigated factors influencing the success of $A B$ pleurodesis. For instance, the use of non-steroid antiinflammatory medications after the procedure were suggested to reduce efficacy [32], while the addition of ozone to $1 \mathrm{ml} / \mathrm{kg} \mathrm{AB}$ (50:50) was suggested to increase pleurodesis effectiveness [33]. These findings, although limited, may explain the varying degrees of $\mathrm{AB}$ success reported in different clinical studies.

In our experimental study, pleurodesis was best achieved in the Talc and AB groups. Previous studies in animals are often intriguing; however, consistent results have not been reported with any of the methods. Experimental animal studies have frequently utilized Talc as the primary agent to be compared with other candidate agents; however, the majority have reported superior Talc efficacy in both microscopic and macroscopic investigations $[18,19]$. The exception to this seems to be doxycycline which demonstrated significant superiority to Talc in a rabbit study by Mitchem and colleagues, albeit with severe local (and possibly systemic) side effects; thus, the authors themselves concluded that preferring Talc over doxycycline would be beneficial [20]. They also found that $A B$ application was not effective in the short term [20]. On the other hand, results with PI in animal experiments seem to be promising. A remarkably detailed rabbit study, comparing PI at 3 different concentrations (2, 4 and 10\%), by Teixeira and coworkers, revealed that PI was effective in pleurodesis formation (at 4 and 10\% concentrations) in 7 days. They also found that macroscopic findings associated with adhesion had progressively increased with concentration and duration, indicating a somewhat reliable dose-response characteristic. Moreover, no adverse effects were reported in the study [15].

Table 2 Comparison of inflammation levels between the experimental groups

\begin{tabular}{|c|c|c|c|c|c|c|c|c|c|c|}
\hline & \multicolumn{2}{|c|}{ Control $(n=8)$} & \multicolumn{2}{|c|}{$\mathrm{PI}(n=6)$} & \multicolumn{2}{|c|}{ Talc $(n=7)$} & \multicolumn{2}{|c|}{$\mathrm{AB}(n=7)$} & \multicolumn{2}{|c|}{ HES $(n=8)$} \\
\hline & $\bar{n}$ & $\%$ & $\bar{n}$ & $\overline{\%}$ & $\bar{n}$ & $\%$ & $\bar{n}$ & $\%$ & $\bar{n}$ & $\%$ \\
\hline Non-existent & $7 \mathrm{a}$ & 87.5 & $\mathrm{O}_{\mathrm{b}}$ & 0 & $\mathrm{O}_{\mathrm{b}}$ & 0 & $\mathrm{O}_{\mathrm{b}}$ & 0 & $3 \mathrm{~b}$ & 37.5 \\
\hline Inflammation between $>0-5 \%$ & $1_{a}$ & 12.5 & 3 a. b & 50 & $3_{\text {a. b }}$ & 42.9 & $2 \mathrm{a} . \mathrm{b}$ & 28.6 & $5 b$ & 62.5 \\
\hline Inflammation between > 5-30\% & $0_{a}$ & 0 & $3_{b}$ & 50 & $4_{b}$ & 57.1 & $3 b$ & 42.9 & $\mathrm{O}_{\mathrm{a}}$ & 0.0 \\
\hline Inflammation between > 30-100\% & $0_{a}$ & 0 & $0_{a}$ & 0 & $0_{a}$ & 0 & $2 a$ & 28.6 & $\mathrm{O}_{\mathrm{a}}$ & 0.0 \\
\hline
\end{tabular}

Pearson Chi-square test with subset comparison for column proportions. Chi-Square $=35.633, p<0.001$. Percentages represent column proportion. The same letters indicate the lack of significant difference from other group subsets (No correction for multiple hypothesis testing) 
Table 3 Comparison of fibrosis levels between the experimental groups

\begin{tabular}{|c|c|c|c|c|c|c|c|c|c|c|}
\hline & \multicolumn{2}{|c|}{ Control $(n=8)$} & \multicolumn{2}{|c|}{ PI $(n=6)$} & \multicolumn{2}{|c|}{ Talc $(n=7)$} & \multicolumn{2}{|c|}{$\mathrm{AB}(n=7)$} & \multicolumn{2}{|c|}{ HES $(n=8)$} \\
\hline & $\mathrm{n}$ & $\%$ & $n$ & $\%$ & $\mathrm{n}$ & $\%$ & $n$ & $\%$ & $n$ & $\%$ \\
\hline No fibrosis (0\%) & $8 a$ & 100 & $\mathrm{O}_{\mathrm{b}}$ & 0 & $1_{b}$ & 14.3 & $O_{b}$ & 0 & $8 a$ & 100 \\
\hline Fibrosis between > 0-5\% & $0_{a}$ & 0 & $\sigma_{b}$ & 100 & $4_{b}$ & 57.1 & $5 b$ & 71.4 & $0_{a}$ & 0 \\
\hline Fibrosis between > 5-30\% & $0_{a}$ & 0 & $0_{a}$ & 0 & $2 a$ & 28.6 & $2 a$ & 28.6 & $\mathrm{O}_{\mathrm{a}}$ & 0 \\
\hline
\end{tabular}

Pearson Chi-square test with subset comparison for column proportions. Chi-Square $=36.928, p<0.001$. Percentages represent column proportion. The same letters indicate the lack of significant difference from other group subsets (No correction for multiple hypothesis testing)

Studies reporting adverse effects with different types of chemical pleurodesis are conflicting. For instance, various concentrations have been utilized for Talc pleurodesis $(40-500 \mathrm{mg} / \mathrm{kg}$ ) with a broad range of study durations ( $72 \mathrm{~h}-45$ days); however, these studies have failed to determine whether an increase in dosage is associated with the development of pleurodesis or not, even though it is often noted that smaller particle size of Talc may be associated with adverse events $[18,19,34$, 35]. Furthermore, while Gozubuyuk et al. [34] reported significant side effects (including edema and hemorrhage) and Muta et al. [19] detected Talc particles in the alveoli, studies similar in design have not found such results [18, 35]. Our assessment of the contralateral side and other tissues via macroscopic and microscopic analyses did not show any adverse effects with the agents used in the current study. However, biochemical and systemic evaluations were not performed.

In a prospective study of 56 patients with malignant pleural effusion, Keeratichananont et al. compared autologous pleurodesis and talcum powder, and demonstrated that they had an equivalent efficacy. Moreover, they reported that recipients of $A B$ had significantly lower fever, pain score and length of hospital stay [36].

In another clinical study, Ibrahim et al. evaluated 38 patients with malignant pleural effusion in a prospective study comparing PI and Talc for pleurodesis. Their results showed that PI was an effective alternative to Talc [37]. In our study, we observed that PI was not as effective when compared to the $\mathrm{AB}$ and Talc groups. However, this observation may be confounded by the loss of 2 rats immediately after the procedure in the PI group. It is well known that PI causes contact dermatitis, allergic reactions, chemical burns, and irritant skin lesions [38]. In another study, Cheong et al. [39] observed that PI causes an initial inflammatory phase with edema, alveolar rupture, and leukocyte infiltration into the pulmonary interstitium. Even though previous studies have not reported significant side-effects with PI [15], we believe that immediate postinterventional loss of subjects in this study may be associated with acute adverse reactions.

The hypothesis of our study was conceived based on the findings of Sun and colleagues. They had suggested that HES could be used safely as an alternative to epidural blood patches [12]. Our results demonstrated a statistically significant effect of HES in comparison to controls; however, efficacy was not comparable to those seen in the PI, Talc and AB groups. Although statistical significance was not observed in the majority of comparisons between these 3 groups, the trends observed in our study indicate that the most effective agents were Talc and $\mathrm{AB}$. In clinical practice, $\mathrm{AB}$ pleurodesis has gained widespread use for the treatment of persistent air leaks, especially in patients with spontaneous pneumothorax where the use of Talc cannot be considered due the possibility of severe adverse events. It is also important to note that $\mathrm{AB}$ has virtually no side effects compared to other chemical agents.

In this experimental study, although HES application caused significant variations from controls, our results do not support a reliable role for HES in pleurodesis.
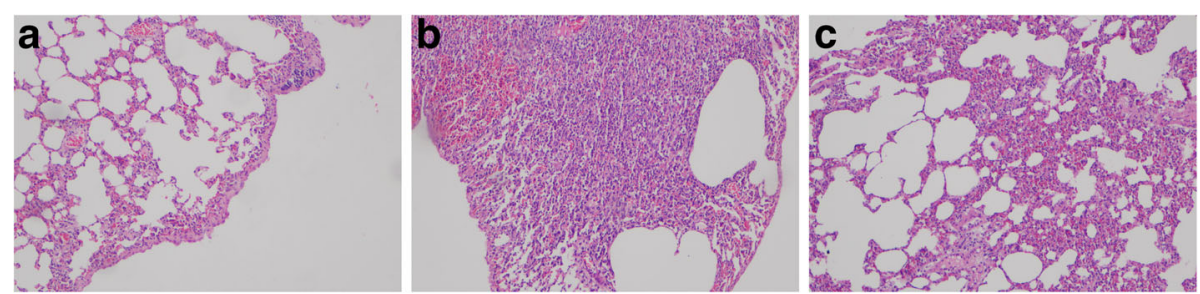

Fig. 4 Microscopic evaluations in the different groups. a: Sterile Talcum group; Development of fibrosis in the visceral pleura (arrow) and emphysematous changes in the subpleural area. H\&E, $\times 100$. b: Autologous blood transfusion group; Development of mild fibrosis in the visceral pleura around intense parenchymal inflammation areas (arrow). H\&E, $\times 100$. c: HES 130/0.4 (6\%) group; Intense inflammatory response and mild emphysematous changes, H\&E, $\times 100$ 
Table 4 Detailed evaluation of previous experimental animal studies (rats and rabbits) of pleurodesis

\begin{tabular}{|c|c|c|c|c|c|c|}
\hline Agent & Study & Species & Dosage & Duration & Toxicity & Notes \\
\hline \multirow[t]{3}{*}{$\begin{array}{l}\text { Povidone- } \\
\text { iodine }\end{array}$} & $\begin{array}{l}\text { Teixeira et al. } \\
2013 \text { [15] }\end{array}$ & $\begin{array}{l}\text { New } \\
\text { Zealand } \\
\text { rabbits (2- } \\
3 \mathrm{~kg})\end{array}$ & $\begin{array}{l}2 \mathrm{ml} @ 2, \\
4 \text { and } \\
10 \%\end{array}$ & $\begin{array}{l}1,3,7 \\
14,28 \\
\text { days }\end{array}$ & $\begin{array}{l}\text { No adverse effects despite relatively high } \\
\text { dosage }\end{array}$ & $\begin{array}{l}\text { Macroscopic results showed } \\
\text { progressive increase in adhesion } \\
\text { with dosage ( } 4 \text { and 10\%) and time } \\
\text { (demonstrating a plateau after } 7 \\
\text { days) }\end{array}$ \\
\hline & $\begin{array}{l}\text { Lashkarizadeh } \\
\text { et al. } 2019 \\
\text { [13] }\end{array}$ & $\begin{array}{l}\text { Rats (details } \\
\text { not } \\
\text { understood) }\end{array}$ & $\begin{array}{l}0.5 \mathrm{ml} @ \\
8 \%\end{array}$ & 45 days & No information & $\begin{array}{l}\text { Povidone-iodine had similar } \\
\text { effectivity with Talc. }\end{array}$ \\
\hline & $\begin{array}{l}\text { Yazkan et al. } \\
2013[14]\end{array}$ & $\begin{array}{l}\text { Wistar- } \\
\text { albino rats } \\
(260-320 \mathrm{~g})\end{array}$ & $\begin{array}{l}2 \mathrm{ml} @ 1 \\
2 \text { and } 4 \%\end{array}$ & 30 days & $\begin{array}{l}\text { Although } 4 \% \text { dosage demonstrated some } \\
\text { microscopic adverse effects in the } \\
\text { contralateral pleura, statistical significance } \\
\text { was not present. }\end{array}$ & $\begin{array}{l}2 \text { and } 4 \% \text { dosage deemed to be } \\
\text { similar in effect, and both were } \\
\text { better than } 1 \% \text {. All three } \\
\text { concentrations were deemed safe, } \\
\text { but } 2 \% \text { was advised. }\end{array}$ \\
\hline \multirow[t]{6}{*}{ Talc } & $\begin{array}{l}\text { Vanucci et al. } \\
2018[22]\end{array}$ & $\begin{array}{l}\text { New } \\
\text { Zealand } \\
\text { rabbits }(2.1- \\
2.5 \mathrm{~kg})\end{array}$ & $\begin{array}{l}2 \mathrm{ml} @ \\
40 \mathrm{mg} / \mathrm{kg} \\
\text { and } 200 \\
\mathrm{mg} / \mathrm{kg}\end{array}$ & $\begin{array}{l}14 \text { and } \\
28 \text { days }\end{array}$ & $\begin{array}{l}\text { Pleural granulomas were observed with } \\
\text { both doses in all subjects on day } 14 \text {. In the } \\
40 \mathrm{mg} / \mathrm{kg} \text { group, only } 40 \% \text { of the subjects } \\
\text { had granulomas on the } 28 \text { th day. All } 200 \\
\text { mg/kg recipients had granulomas on the } \\
28 \text { th day. }\end{array}$ & $\begin{array}{l}\text { Adhesion did not seem to increase } \\
\text { with higher dosage, but somewhat } \\
\text { increased with time ( } 14 \text { vs. } 28 \text { days) }\end{array}$ \\
\hline & $\begin{array}{l}\text { Gozubuyuk } \\
\text { et al. } 2010 \\
{[23]}\end{array}$ & $\begin{array}{l}\text { Wistar- } \\
\text { albino rats } \\
(280-320 \mathrm{~g})\end{array}$ & $\begin{array}{l}0.5 \mathrm{ml} @ \\
60 \mathrm{mg} / \mathrm{kg}\end{array}$ & $\begin{array}{l}72 \mathrm{~h} \\
\text { and } 7 \\
\text { days }\end{array}$ & $\begin{array}{l}\text { Significant alveolar edema, hemorrhage and } \\
\text { inflammation in the acute phase }(72 \mathrm{~h}) \\
\text { compared to tetracycline and controls. At } 7 \\
\text { days, edema was also present at a higher } \\
\text { frequency. }\end{array}$ & $\begin{array}{l}\text { Results were compared with } \\
\text { tetracycline, and showed that Talc } \\
\text { caused earlier pleural proliferation } \\
\text { and fibrosis. }\end{array}$ \\
\hline & $\begin{array}{l}\text { Ahn et al. } \\
2015[18]\end{array}$ & $\begin{array}{l}\text { Sprague- } \\
\text { Dawley rats } \\
(220-300 \mathrm{~g})\end{array}$ & $\begin{array}{l}400 \mathrm{mg} / \\
\mathrm{kg} \\
\text { (volume } \\
\text { not } \\
\text { reported) }\end{array}$ & 28 days & $\begin{array}{l}\text { Talc particles not detected in lung } \\
\text { parenchyma. Suggested possibility for } \\
\text { systemic effect. }\end{array}$ & \\
\hline & $\begin{array}{l}\text { Muta et al. } \\
2011[19]\end{array}$ & $\begin{array}{l}\text { Wistar rats } \\
(300-350 \mathrm{~g})\end{array}$ & $\begin{array}{l}400 \mathrm{mg} / \\
\mathrm{kg} \\
\text { (volume } \\
\text { not } \\
\text { reported) }\end{array}$ & 30 days & Talc particles detected in the alveoli. & \\
\hline & $\begin{array}{l}\text { Refosco et al. } \\
2004 \text { [24] }\end{array}$ & $\begin{array}{l}\text { Wistar rats } \\
(200-300 \mathrm{~g})\end{array}$ & $\begin{array}{l}2 \mathrm{ml} @ \\
100 \mathrm{mg} / \\
\mathrm{kg} \text { and } \\
500 \mathrm{mg} / \\
\mathrm{kg}\end{array}$ & 45 days & Too few subjects to evaluate toxicity. & $\begin{array}{l}\text { No remarkable differences between } \\
\text { the two very different doses. }\end{array}$ \\
\hline & $\begin{array}{l}\text { Mitchem et al. } \\
1999[20]\end{array}$ & $\begin{array}{l}\text { New } \\
\text { Zealand } \\
\text { rabbits ( } 4 \\
\mathrm{~kg})\end{array}$ & $\begin{array}{l}\sim 0.25 \mathrm{ml} \\
@ 70 \mathrm{mg} / \\
\mathrm{kg}\end{array}$ & 30 days & $\begin{array}{l}\text { Histological changes in the contralateral } \\
\text { lung and blood chemistry changes. } \\
\text { Suggested systemic adverse effect. }\end{array}$ & $\begin{array}{l}\text { Although adverse effects were } \\
\text { observed, authors concluded Talc } \\
\text { was safer than doxycycline (other } \\
\text { group). }\end{array}$ \\
\hline \multirow[t]{4}{*}{$\begin{array}{l}\text { Autologous } \\
\text { Blood }\end{array}$} & $\begin{array}{l}\text { Ozpolat et al. } \\
2010[16]\end{array}$ & $\begin{array}{l}\text { Wistar- } \\
\text { albino rats } \\
(280-310 \mathrm{~g})\end{array}$ & $\begin{array}{l}1 \mathrm{ml} / \mathrm{kg} \\
2 \mathrm{ml} / \mathrm{kg} \\
\text { and } 3 \mathrm{ml} / \\
\mathrm{kg}\end{array}$ & 30 days & $\begin{array}{l}\text { No microscopic or macroscopic adverse } \\
\text { effects in the contralateral pleura and other } \\
\text { tissues. No systemic effects. }\end{array}$ & $\begin{array}{l}1 \mathrm{ml} / \mathrm{kg} \text { did not cause adhesion, } 2 \\
\mathrm{ml} / \mathrm{kg} \text { was effective but } 3 \mathrm{ml} / \mathrm{kg} \text { was } \\
\text { deemed more appropriate. }\end{array}$ \\
\hline & $\begin{array}{l}\text { Yalcinkaya } \\
\text { et al. } 2019 \\
\text { [25] }\end{array}$ & $\begin{array}{l}\text { Wistar- } \\
\text { albino rats } \\
(250-300 \mathrm{~g})\end{array}$ & $3 \mathrm{ml} / \mathrm{kg}$ & $\begin{array}{l}7 \text { and } \\
21 \text { days }\end{array}$ & $\begin{array}{l}\text { At least } 1 \text { rat died before the end of the } \\
\text { study in each group. }\end{array}$ & $\begin{array}{l}\text { NSAIDs seemed to reduce the } \\
\text { formation of pleurodesis when used } \\
\text { after the intervention. }\end{array}$ \\
\hline & $\begin{array}{l}\text { Yildizhan et al. } \\
2016 \text { [26] }\end{array}$ & $\begin{array}{l}\text { Wistar- } \\
\text { albino rats } \\
(260-320 \mathrm{~g})\end{array}$ & $2 \mathrm{ml} / \mathrm{kg}$ & 30 days & $\begin{array}{l}\text { No inflammation or adhesion in the } \\
\text { contralateral pleura, liver or diaphragm. No } \\
\text { sign of alveolar injury. }\end{array}$ & $\begin{array}{l}\text { A group which received a } 50: 50 \text { mix } \\
\text { of ozone and } 1 \mathrm{ml} / \mathrm{kg} \text { autologous } \\
\text { blood demonstrated better results } \\
\text { compared to autologous blood } \\
\text { alone }(2 \mathrm{ml} / \mathrm{kg}) \text {. }\end{array}$ \\
\hline & $\begin{array}{l}\text { Mitchem et al. } \\
1999 \text { [20] }\end{array}$ & $\begin{array}{l}\text { New } \\
\text { Zealand } \\
\text { rabbits (4 } \\
\mathrm{kg})\end{array}$ & $1 \mathrm{ml} / \mathrm{kg}$ & 30 days & No adverse effects. & $\begin{array}{l}\text { No efficacy in contrast to Talc and } \\
\text { doxycycline which had significant } \\
\text { efficacy. }\end{array}$ \\
\hline
\end{tabular}




\section{Limitations}

The prominence of inflammation but the absence of comparable fibrosis may be interpreted as a limitation associated with the lack of sufficient time for the development of fibrosis. However, even though the study duration may be considered short in comparison to a few of the studies on this topic, the median duration of such studies is around 30 days. Furthermore, it is also apparent that the Talc and $\mathrm{AB}$ groups demonstrated significant effects within this 30-day period; thus the study duration was undoubtedly sufficient to test our hypothesis. Another limitation is the low number of subjects in each group, which was compounded by the loss of a total of 4 rats before planned sacrification. However, low number of subjects are a natural limitation in all animalbased studies, and the evaluation of previously published studies shows that the number of animals included in the final analysis were sufficient to draw conclusions.

\section{Conclusion}

Even though our results did not show success with HES, we believe that future studies aimed at identifying better agents for pleurodesis will continue unabated due to the unreliable outcomes and adverse effects of available treatments. Easy access, low cost and good safety profile are probably the most crucial factors that will affect the search for an ideal pleurodesis agent. Even though HES application seems to be ineffective, our results indicate that the $\mathrm{AB}$ pleurodesis method remains as a safe, simple and cheap option that is considerably effective.

\section{Abbreviations}

AB: Autologous blood; COMUDAM: Canakkale Onsekiz Mart University Experimental Research Application and Research Center; H\&E: Hematoxylin \& Eosin; HES: Hydroxyethyl Starch 130/0.4 (6\%); PI: Povidone-iodine; PTFE: Polytetrafluoroethylene; SF: Physiological Saline

\section{Acknowledgments \\ This is research was supported by the Scientific Research Projects Coordination Unit of Canakkale Onsekiz Mart University as an "Independent Research Project" (Grant Number: 2018/1800097318). I would like to thank veterinarian Dr. Sait Elmas and the entire staff of Canakkale Onsekiz Mart University experimental research application and research center.}

\section{Authors' contributions}

All authors have read and approved the manuscript. Concept and Design HOK, HAK, NDG. Data Collection and/or Processing - HOK, HAK. Analysis and/or Interpretation - HOK, HAK, NDG. Literature Search - HOK, HAK. Writing Manuscript - HOK, HAK. Critical Review - HOK, HAK, NDG.

\section{Funding}

This research was supported by Çanakkale Onsekiz Mart Üniversitesi Bilimse Araşatırma Projeleri (ÇOMU BAP) Coordination Unit with a grant code of THD-2018-2763. There is no role of the funding body in the design of the study and collection, analysis, and interpretation of data and in writing the manuscript.

\section{Availability of data and materials}

The datasets generated and/or analyzed during the current study are not publicly available due to the use of a grant from COMUDAM, but are available from the corresponding author on reasonable request.

\section{Ethics approval and consent to participate}

Ethical approval was obtained from the Canakkale Onsekiz Mart University Ethical Board of Animal Studies (Decision number: 2018/1800097318).

\section{Consent for publication}

Not applicable.

\section{Competing interests}

The authors declare no competing interests in association with present study.

\section{Author details}

${ }^{1}$ Department of Thoracic Surgery, Canakkale Onsekiz Mart University, Faculty of Medicine, Canakkale, Turkey. ${ }^{2}$ Department of Anesthesiology, Canakkale Onsekiz Mart University Faculty of Medicine, Canakkale, Turkey. ${ }^{3}$ Department of Pathology, Izmit Seka State Hospital, İmit, Kocaeli, Turkey.

Received: 17 February 2020 Accepted: 5 August 2020

Published online: 27 August 2020

\section{References}

1. Light RW. Diseases of the pleura: the use of talc for pleurodesis. Curr Opin Pulm Med. 2000;6(4):255-8.

2. Ş̧enyiğit A. Plöredezisde sık kullanılan ajanlar. Türk Toraks Derneği Plevra Bülteni. 2009:3:2

3. Walker-Renard PB, Vaughan LM, Sahn SA. Chemical pleurodesis for malignant pleural effusions. Ann Intern Med. 1994;120(1):56-64.

4. Yazkan R. Rapid pleurodesis in malignant pleural effusion: a clinical study and literature review. Turk J Thoracic Cardiovasc Surg. 2011;19(3):410-6.

5. Yildirim E, Dural K, Yazkan R, Zengin N, Yildirim D, Gunal N, et al. Rapid pleurodesis in symptomatic malignant pleural effusion. Eur J Cardiothorac Surg. 2005:27(1):19-22.

6. De Andrade FM, Pereira MR, Kilesse RL, Farnetano BDS. Autologous blood patch pleurodesis: an effective but underused method. J Cardiothorac Surg. 2004;26:897-900.

7. Kennedy L, Rusch WW, Strange C, Ginsberg RJ, Sahn SA. Pleurodesis using talc slurry. Chest. 1994;106(2):342-6.

8. Milanez Campos J, Werebe C, Vargas FS, Jatene FB, Light RW. Respiratory failure due to insufflated talc. Lancet (British edition). 1997;349(9047):251-2.

9. De Campos JRM, Cardoso P, Vargas FS, De Campos WE, Teixeira LR, Jatene FB, et al. Thoracoscopy talc poudrage: a 15-year experience. Chest. 2001; 119(3):801-6.

10. Krabbe J, Ruske N, Braunschweig T, Kintsler S, Spillner JW, Schröder T, et al. The effects of hydroxyethyl starch and gelatine on pulmonary cytokine production and oedema formation. Sci Rep. 2018:8(1):1-11.

11. Kozek-Langenecker SA, Jungheinrich C, Sauermann W, Van Der Linden P. The effects of hydroxyethyl starch 130/0.4 (6\%) on blood loss and use of blood products in major surgery: a pooled analysis of randomized clinical trials. Anesth Analg. 2008;107(2):382-90.

12. Sun S, Huang S-Q. Epidural injection of hydroxyethyl starch in the management of post-dural puncture headache: a case series. Int J Clin Exp Med. 2015;8(5):8254

13. Lashkarizadeh MR, Pourdavood A, Salehi AR, Amirbeigi A. Comparing the effect of ethanol amine, Povidone-iodine and talcum powder on induction of Pleurodesis in rats. J Mazandaran Univ Med Sci. 2019;29(178):107-14.

14. Yazkan R, Özpolat B, Ergene G. lodopovidone pleurodesis in the treatment of refractory pleural effusions. Türk Göğüs Kalp Damar Cerrahisi Dergisi. 2013:21(1):106-9.

15. Teixeira LR, Vargas FS, Puka J, Acencio MM, Antonangelo L, Terra RM, et al. Effectiveness and safety of iodopovidone in an experimental pleurodesis model. Clinics. 2013;68(4):557-62.

16. Özpolat B, Gazyagci S, Gözübüyük A, Ayva Ş, Atinkaya C. Autologous blood pleurodesis in rats to elucidate the amounts of blood required for reliable and reproducible results. J Surg Res. 2010;161(2):228-32.

17. Hurewitz AN, Lidonicci $K$, Wu CL, Reim D, Zucker S. Histologic changes of doxycycline pleurodesis in rabbits: effect of concentration and $\mathrm{pH}$. Chest. 1994;106(4):1241-5.

18. Ahn HY, Cho JS, Kim YD, Hoseok I, Kim YJ, Kim A, et al. Efficacy of mistletoe for chemical pleurodesis in rats without malignancy. Open Medicine. 2015; 10(1):346-51. 
19. Muta F, Takamori S, Matsuo T, Iwasaki Y, Yoshiyama K, Shirouzu K. Changes in the pleural cavity by pleurodesis using talc or OK-432: an experimental study. Surg Today. 2011;41(1):111-4.

20. Mitchem RE, Herndon BL, Fiorella RM, Molteni A, Battie CN, Reisz GR. Pleurodesis by autologous blood, doxycycline, and talc in a rabbit model. Ann Thorac Surg. 1999;67(4):917-21.

21. Das A, Shah PS. Octreotide for the treatment of chylothorax in neonates. Cochrane Database Syst Rev. 2010;9:CD006388.

22. Ando M, Yamamoto M, Kitagawa C, Kumazawa A, Sato M, Shıma K, et al. Autologous blood-patch pleurodesis for secondary spontaneous pneumothorax with persistent air leak. Respir Med. 1999;93(6):432-4.

23. Chadwick C, Marven S, Vora A. Autologous blood pleurodesis for pneumothorax complicating graft-versus-host disease-related bronchiolitis obliterans. Bone Marrow Transplant. 2004;33(4):451-3.

24. Lang-Lazdunski L, Coonar AS. A prospective study of autologous 'blood patch'pleurodesis for persistent air leak after pulmonary resection. Eur J Cardiothorac Surg. 2004;26(5):897-900.

25. Robinson C. Autologous blood for pleurodesis in recurrent and chronic spontaneous pneumothorax. Can J Surg. 1987;30(6):428.

26. Manley K, Coonar A, Wells F, Scarci M. Blood patch for persistent air leak: a review of the current literature. Curr Opin Pulm Med. 2012;18(4):333-8.

27. Athanassiadi K, Bagaev E, Haverich A. Autologous blood pleurodesis for persistent air leak. Thorac Cardiovasc Surg. 2009;57(08):476-9.

28. De Andrés JJR, Blanco S, De La Torre M. Postsurgical pleurodesis with autologous blood in patients with persistent air leak. Ann Thorac Surg. 2000;70(1):270-2.

29. Droghetti A, Schiavini A, Muriana P, Comel A, De Donno G, Beccaria M, et al. Autologous blood patch in persistent air leaks after pulmonary resection. J Thorac Cardiovasc Surg. 2006;132(3):556-9.

30. Andreetti C, Venuta F, Anile M, De Giacomo T, Diso D, Di Stasio M, et al. Pleurodesis with an autologous blood patch to prevent persistent air leaks after lobectomy. J Thorac Cardiovasc Surg. 2007;133(3):759-62.

31. Refosco TJ, Dutra I, Schneider A. Estudo das alterações ultra-estruturais em pleura de ratos pós pleurodese por talco. Revista do Colégio Brasileiro de Cirurgiões. 2004:31(6):345-8.

32. Yalçınkaya S, Yalçınkaya U. Non-steroid anti-inflammatory drugs reduce the efficacy of autologous blood pleurodesis. Turk J Thorac Cardiovascr Surg. 2019;27(3):343

33. Yıldızhan A, Candaş F, Yavuz Ö, et al. Does medical ozone increase the pleurodesis effectiveness of autologous blood? Turk J Thorac Cardiovasc Surg. 2016;24(4):736-40.

34. Gözübüyük A, Özpolat B, Çiçek AF, Çaylak H, Yücel O, Kavaklı K, et al. Comparison of side effects of oxytetracycline and talc pleurodesis: an experimental study. J Cardiothorac Surg. 2010;5(1):128.

35. Vannucci J, Bellezza G, Matricardi A, Moretti G, Bufalari A, Cagini L, et al. Observational analysis on inflammatory reaction to talc pleurodesis: small and large animal model series review. Exp Ther Med. 2018;15(1):733-8.

36. Keeratichananont W, Kaewdech A, Keeratichananont S. Efficacy and safety profile of autologous blood versus talc pleurodesis for malignant pleural effusion: a randomized controlled trial. Ther Adv Respir Dis. 2018;12: 1753466618816625.

37. Ibrahim IM, Dokhan AL, El-Sessy AA, Eltaweel MF. Povidone-iodine pleurodesis versus talc pleurodesis in preventing recurrence of malignant pleural effusion. J Cardiothorac Surg. 2015;10(1):1-6.

38. Durani $P$, Leaper D. Povidone-iodine: use in hand disinfection, skin preparation and antiseptic irrigation. Int Wound J. 2008;5(3):376-87.

39. Cheong SH, Yang Yl, Choi MY, Kim MH, Cho KR, Lim SH, et al. Lung injury induced by the pulmonary instillation of povidone-iodine in rats. J Anesth. 2012;26:70-9.

\section{Publisher's Note}

Springer Nature remains neutral with regard to jurisdictional claims in published maps and institutional affiliations.

Ready to submit your research? Choose BMC and benefit from:

- fast, convenient online submission

- thorough peer review by experienced researchers in your field

- rapid publication on acceptance

- support for research data, including large and complex data types

- gold Open Access which fosters wider collaboration and increased citations

- maximum visibility for your research: over $100 \mathrm{M}$ website views per year

At BMC, research is always in progress.

Learn more biomedcentral.com/submissions 